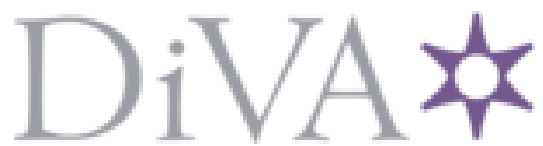

http://www.diva-portal.org

This is the published version of a paper published in Management Revue.

Citation for the original published paper (version of record):

Cyron, T., Zoellick, J C. (2018)

Business development in post-growth economies: Challenging assumptions in the existing business growth literature

Management Revue, 29(3): 206-229

https://doi.org/10.5771/0935-9915-2018-3-206

Access to the published version may require subscription.

N.B. When citing this work, cite the original published paper.

Permanent link to this version:

http://urn.kb.se/resolve?urn=urn:nbn:se:hj:diva-41957 
Thomas Cyron, Jan Cornelius Zoellick*

\title{
Business Development in Post-Growth Economies: Challenging Assumptions in the Existing Business Growth Literature
}

\begin{abstract}
Existing literature has not specifically examined individual business growth in postgrowth economies. This paper challenges dominant assumptions in the business growth literature by considering post-growth economies as an organisational context characterised by natural resource scarcity and an absence of macro-level economic expansion. We investigate conceptually how such a context impacts business growth theory by seeking to answer three major questions: (1) What is business growth? (2) Why do businesses grow? (3) And how do businesses grow? Accordingly, post-growth contexts pose three major challenges to business growth theorising: (1) business growth as an increase in measurable outcomes, (2) resource competition and dispositive path dependencies, and (3) detrimental growth modes and strategies. Based upon six revised assumptions, we re-define business development in line with forces at work in post-growth economies. We further suggest a multidimensional research agenda that can catalyse future discussions of post-growth organisations. These discussions have the potential to overcome the inertia in business growth theory and its discrepancies with practice.
\end{abstract}

Keywords: Conceptual paper, business development, problematisation, degrowth, sustainability (JEL: M00, M10, O12, Q50)

\section{Introduction}

What does it mean for an individual firm if the economy it participates in cannot or should not continue to expand? In the second half of the $20^{\text {th }}$ century, a dogmatic socio-economic context has developed (Schmelzer, 2016) that incentivises, fosters, and almost prescribes quantitative growth for firms and the overall economy, even in the face of ecological degradation and social and economic inequality. However, the macro-level alternative - a post-growth context - is neither well elaborated nor understood, particularly regarding its effects on the individual firm. Macro-level analyses cannot simply be translated verbatim into meso and micro levels. Halting

* Thomas Cyron (corresponding author): Jönköping International Business School, Jönköping University, Gjuterigatan 5, 55111 Jönköping, Sweden. E-mail: thomas.cyron@ju.se Jan Cornelius Zoellick: Charité - Universitätsmedizin Berlin, corporate member of Freie Universität Berlin, Humboldt-Universität zu Berlin, and Berlin Institute of Health Institute of Medical Sociology and Rehabilitation Science, Charitéplatz 1, 10117 Berlin, Germany and Institute of Sociology, Goethe-University Frankfurt am Main

mrev, 29 (3) 2018, $206-229$

DOI: 10.5771/0935-9915-2018-3-206 
the establishment, development, and even growth of individual firms would decrease flexibility, increase transaction costs, and create stagnation.

Currently, critical management scholars (e.g., Atzeni, 2012; Johnsen, Nelund, Olaison, \& Sørensen, 2017; Parker, Cheney, Fournier, \& Land, 2014) and ecology-oriented literature (e.g., Dietsche \& Liesen, 2013; Palzkill \& Schneidewind, 2013) are leading the debate in the emerging field of post-growth organisations. Their contributions, however, often reside in a theoretical niche, with little impact on more general discussions - for two reasons. First, they remain silent regarding the role and character of growth in post-growth organisations. Some acknowledge that business growth cannot simply be halted in post-growth contexts (Gebauer \& Ziegler, 2013; Reichel, 2013). Others suggest how renewed theorising on business growth might look (e.g. Reichel, 2017a; Roth, 2017). However, these and similar publications do not explicitly build on the existing business growth literature. In that sense, they risk ending up with "prepackaged problematization attempts" (Alvesson \& Sandberg, 2011, p. 252) that oppose theoretical and political agendas instead of meaningfully challenging existing beliefs. Second, many scholars suggest rather unorthodox solutions to major challenges facing post-growth economies without challenging the assumptions in management theory. Because they speak a different dialect regarding theory, their ideas rarely resonate in management literature at large and in business growth theory in particular.

In contrast, we define the role of business growth for post-growth organisations by thoroughly examining major existing theoretical assumptions. We thus aim to overcome the insignificance of post-growth theorising by translating the ideas into the dialect of mainstream theories. Our theoretical reasoning is guided by Penrose (1959), who established managers and their use of idle resources as major drivers of firm development. Although Penrose's theory and her successors remain eminent contributions in the business growth literature (McKelvie \& Wiklund, 2010; Nason \& Wiklund, 2018), Lockett et al. (2011) argue that her reasoning is a product of its age. The 1950s were characterised by extensive macro-economic expansion, leading Penrose to discard any external limits to business growth. Currently, however, economic growth has weakened and competition has increased, so the "assumption of unlimited growth opportunities does not hold” (Lockett et al., 2011, p. 49).

We provide a different perspective by acknowledging empirical aspects of postgrowth economies. Early-industrialised economies grow at low rates (World Bank, 2017), and multinational enterprises struggle to maintain their previous expansion (Fisher, Gaul, \& Kleinberger, 2017). Correspondingly, post-growth describes an existing economic context embedding the individual firm. We apply the methodology of problematisation (cf. Alvesson \& Sandberg, 2011) to explicitly tackle the assumptions in business growth literature, and critically assess their applicability to the new post-growth context. Rather than seeing its constraints, we explore what 
opportunities the post-growth context provides for the developmental growth of the individual firm.

We contribute to the literature in several ways. First, we identify three major challenges that necessitate revisions to the common assumptions in business growth literature. Second, by considering these revisions, we define business development in a post-growth context as a qualitative and collaborative process that subordinates the role of business growth to foster resourcefulness and emancipation of market participants. Finally, the revised assumptions further serve as major pillars of a common research agenda that can guide future theoretical elaborations on post-growth organisations.

Following Alvesson and Sandberg's (2011) problematisation methodology, the text proceeds as follows. First, we identify a coherent literature stream that addresses business growth and articulate its assumptions. Second, we discuss the potential effects of a post-growth context on individual firms. Based upon these insights, we evaluate the necessity of challenging current assumptions. Third, combining insights from existing alternative theoretical and empirical viewpoints, we offer alternative assumptions where necessary. We then relate the revised assumptions to the existing literature and integrate them into a conceptual framework for business development in post-growth economies.

\section{Unpacking Common Assumptions in the Business Growth Literature}

\section{What is Business Growth?}

Business growth literature predominately focuses on growth as increase in some measurable outcome (Achtenhagen, Naldi, \& Melin, 2010; Davidsson, Achtenhagen, \& Naldi, 2010; Leitch, Hill, \& Neergaard, 2010). Indeed, scholars are concerned about finding and explaining the antecedents contributing positively to the growth of individual firms (Davidsson et al., 2010). This focus is justified by equating growth with performance (e.g. Baum, Locke, \& Smith, 2001; Box, Watts, \& Hisrich, 1994; Orser \& Hogarth Scott, 2002) or success (Gundry \& Welsch, 2001; Low \& MacMillan, 1988). In other words, the expansion of the firm is viewed as a contribution to economic development that benefits all involved actors (Miner, Smith, \& Bracker, 1989).

\section{A1: Business growth describes a desired increase in quantity of certain parameters that} contribute to the health and prosperity of the firm and the economy.

\section{Why Do Businesses Grow?}

One major aspect of why businesses grow lies in their existing resources. The resource-based view (RBV) stresses the heterogeneity and immobility of resources, which makes them subject to competition (Barney, 1991; Wernerfelt, 1984). From this perspective, it is not sufficient for a company to possess exploitable resources to 
create new value, but the value must also respond to clear market needs. The more distinct a firm's resource base compared to other market participants, the higher its competitive advantage and potential for growth (Barney, 1991). Accordingly, firms that exploit valuable, rare, inimitable, and non-substitutable (VRIN) resources efficiently and effectively are able to sustain competitive advantages and above-average performance (Barney, 1991). This requires administrative management rather than entrepreneurial spirit.

\section{A2: Firm growth depends on the successful protection of idiosyncratic resources.}

Aside from resources, business growth often depends on individual motivation, especially in small and medium-sized enterprises (SMEs) (Baum et al., 2001; Baum \& Locke, 2004; Wiklund \& Shepherd, 2003). Most smaller firms therefore never grow beyond a certain size (Aldrich, 1999; Cowling, 2006), because many entrepreneurs lack growth motivation (Kolvereid, 1992; Wiklund \& Shepherd, 2003). Individual motivation is often determined by the perceived needs of people managing the organisation and the expected consequences of leading a larger business (Cliff, 1998; Davidsson, 1989; Wiklund, Davidsson, \& Delmar, 2003). According to such logic, firms are much more likely to embark on a growth path if a present opportunity fits a perceived need (Douglas, 2013). Motivation, however, must also be combined with appropriate resources, i.e., knowledge, skills, and experience (Baum et al., 2001; Davidsson, 1991; Wiklund, Patzelt, \& Shepherd, 2009).

While the growth of smaller firms lies in the motivation and capabilities of few individuals, that of larger firms is more dependent upon their structure (Ram, 2000). Following the behavioural approach, a firm develops into different units with autonomous decision-making that depend less on the opinion of a single leader (Cyert \& March, 1963; Gavetti, Greve, Levinthal, \& Ocasio, 2012). According to the general theory of the firm, its profit-making function is the main driver of growth (Penrose, 1955; 1959). Furthermore, the personal development of individual employees might cause the firm to expand in order to create new positions (Penrose, 1959, Posse, 2015).

\section{A3: In smaller firms, the motivation of individuals drives growth; in larger firms, structural reasons prevail.}

Growing businesses often become more hierarchical in order to reduce transaction costs (Canbäck, Samouel, \& Price, 2006). However, more bureaucratic structures are less suitable for entrepreneurial endeavours (Covin \& Slevin, 1988). Transitioning from small to large sizes imposes severe challenges on the growing firm that increase the potential for wasting scarce resources and losing the entrepreneurial spirit (Hofer \& Charan, 1984; Penrose, 1955). Thus, large hierarchical firms are more oriented toward efficiency and the exploitation of existing resources rather than exploring new ideas. 
However, in Penrose's (1959) world of resource accessibility and abundance, firms constantly need to explore available but unused services hidden within the existing resource base. These resources are versatile and enable the firm to gradually develop dynamic capabilities that can provide a foundation for the exploration of hidden resource opportunities (Pettus, 2001). Utilising versatile resources implies entrepreneurial activity. A recent meta-analysis by Nason and Wiklund (2018) reinforces the importance of versatile resources for business growth. It follows that entrepreneurial capabilities are necessary for ongoing expansion.

Taken together, these different factors can be subsumed under the notion of path dependencies. They illustrate how in the Penrosean growth theory "history matters" (Garnsey, Stam, \& Heffernan, 2006, p. 5) meaning that resources in terms of entrepreneurial capabilities (Penrose, 1959) and previously established structures (Greiner, 1972) influence whether a business will grow or not.

Resources and structures are not only drivers of growth, they also influence the direction of business development (Greiner, 1972; Penrose, 1959). Slack resources and the acquisition of new resources provide a toolbox for entrepreneurial activities and firm development. Organisational actors thereby deploy both existing and acquired resources in a new manner so that the firm can expand its existing value proposition in meaningful ways. This new assembly of resources constitutes the base for development in the future, just as previous assemblies influenced the current one (Pettus, 2001).

A4: $\quad$ Versatile resources and excess resources promote business growth; path dependencies influence the direction of growth.

\section{How Do Businesses Grow?}

Research on growth modes offers another perspective on how businesses can grow. Traditionally, researchers have drawn a distinction between organic and acquisitive modes of growth (Lockett \& Wild, 2013; McKelvie \& Wiklund, 2010; Penrose, 1959). Firms that grow organically in one period are less likely to further grow organically in the next (Lockett et al., 2011), because organic growth is a function of a firm's adjustment costs and its productive opportunity set. Once the firm has exploited its available opportunities from the existing resources, it becomes increasingly difficult to grow at the same rate in future periods - a contingency known as the "Penrose effect" (Lockett et al., 2011). Large firms then often decide to grow further through mergers and acquisitions (M\&As) (Ireland, Hitt, Camp, \& Sexton, 2001).

\section{A5: Mo'As compensate for stagnating organic growth.}

Finally, we can examine how businesses grow by considering their strategies. Hereby, strategy works as an intermediary between motivation, resources, and capabili- 
ties as well as the environment (Wiklund, 1998). To remain competitive, managers must adapt their strategy to the overall environment (Aldrich \& Martinez, 2001). Porter (1980) identifies three major strategies: cost efficiency, differentiation, and niche focus. Each of these strategies can eventually generate business growth (Upton, Teal, \& Felan, 2001). Additionally, time-based strategies relate to the timing of market entry (Ireland \& Hitt, 1997). Firms entering first or following early have great potential to grow. An important criterion that determines successful growth is whether the organisation plans far ahead and is able to change its strategy in a flexible and emergent manner (Titus, Covin, \& Slevin, 2011; Upton et al., 2001).

The conclusion, however, that firms should adapt organic structures to retain their flexibility is overly simplistic (Dettmers, Kaiser, \& Fietze, 2013). Empirical evidence indicates that mature industries call for mechanistic structures (Covin \& Slevin, 1990) and aggressive competitive behaviour (Lumpkin \& Dess, 2001), while early and growing industries need organic structures (Covin \& Slevin, 1990) and a proactive orientation (Lumpkin \& Dess, 2001). Entry during the transition period between early and maturing industries shows higher rates of failure, and niche strategies are most appropriate for small firms once the industry is mature (Agarwal, Sarkar, \& Echambadi, 2002). In that respect, firm structure and business growth are not necessarily an individual choice, but might follow from contextual growth drivers.

A6: Firm growth depends on the successful adaptation of strategy and structure according to the dominant market logics.

Table 1 summarizes the identified assumptions in business growth literature. The table also depicts challenges for these assumptions that arise in a post-growth context and outlines suggested revisions. Elaborations on challenges and revisions follow in Sections 3 and 4 . 
Table 1: List of Assumptions in the Managerial Literature, Related Post-Growth Challenges, and Suggested Revisions.

\begin{tabular}{|c|c|c|c|}
\hline Dimension & Assumptions & Challenges & Revised Assumptions \\
\hline $\begin{array}{l}\text { What is } \\
\text { business } \\
\text { growth? }\end{array}$ & $\begin{array}{l}\text { A1: Business growth de- } \\
\text { scribes a desired increase } \\
\text { in quantity of certain pa- } \\
\text { rameters that contribute } \\
\text { to the health and pros- } \\
\text { perity of the firm and the } \\
\text { economy. }\end{array}$ & $\begin{array}{l}\text { C1: Viewing business } \\
\text { growth as an increase in } \\
\text { outcomes is problematic } \\
\text { in limited space. }\end{array}$ & $\begin{array}{l}\text { RA1: Business development } \\
\text { describes an internal, } \\
\text { qualitative process of im- } \\
\text { provement that includes } \\
\text { overcoming challenges. }\end{array}$ \\
\hline \multirow[t]{3}{*}{$\begin{array}{l}\text { Why do } \\
\text { businesses } \\
\text { grow? }\end{array}$} & $\begin{array}{l}\text { A2: Firm growth depends } \\
\text { on the successful protec- } \\
\text { tion of idiosyncratic re- } \\
\text { sources. }\end{array}$ & $\begin{array}{l}\text { C2: Competition for and } \\
\text { exploration of resources } \\
\text { under zero-sum condi- } \\
\text { tions can result in detri- } \\
\text { mental effects. }\end{array}$ & $\begin{array}{l}\text { RA2: Business develop- } \\
\text { ment is resourceful, not re- } \\
\text { source-based. }\end{array}$ \\
\hline & $\begin{array}{l}\text { A3: In smaller firms, the } \\
\text { motivation of individuals } \\
\text { drives growth; } \\
\text { in larger firms, structural } \\
\text { reasons prevail. }\end{array}$ & $\begin{array}{l}\text { C3: More hierarchies and } \\
\text { structures can create dis- } \\
\text { economies of scale. }\end{array}$ & $\begin{array}{l}\text { RA3: Business develop- } \\
\text { ment emancipates firms } \\
\text { from structural growth } \\
\text { drivers. }\end{array}$ \\
\hline & $\begin{array}{l}\text { A4: Versatile resources } \\
\text { and excess resources pro- } \\
\text { mote business growth; } \\
\text { path dependencies influ- } \\
\text { ence the direction of } \\
\text { growth. }\end{array}$ & $\begin{array}{l}\text { C4: Path dependencies } \\
\text { can promote ongoing ex- } \\
\text { pansion. }\end{array}$ & $\begin{array}{l}\text { RA4: Resource versatility } \\
\text { provides the grounds for } \\
\text { resourcefulness and eman- } \\
\text { cipation, not the firm's on- } \\
\text { going expansion. }\end{array}$ \\
\hline \multirow[t]{2}{*}{$\begin{array}{l}\text { How do } \\
\text { businesses } \\
\text { grow? }\end{array}$} & $\begin{array}{l}\text { A5: M\&As compensate } \\
\text { for stagnating organic } \\
\text { growth. }\end{array}$ & $\begin{array}{l}\text { C5: M\&As are wasteful, } \\
\text { problematic, and often } \\
\text { only implemented as } \\
\text { growth drivers. }\end{array}$ & $\begin{array}{l}\text { RA5: Business develop- } \\
\text { ment builds on different } \\
\text { forms of cooperation. }\end{array}$ \\
\hline & $\begin{array}{l}\text { A6: Firm growth depends } \\
\text { on the successful adapta- } \\
\text { tion of strategy and } \\
\text { structure according to the } \\
\text { dominant market logics. }\end{array}$ & $\begin{array}{l}\text { C6: Adapting strategies } \\
\text { and structures to indus- } \\
\text { try standards is problem- } \\
\text { atic because some strate- } \\
\text { gies necessitate expan- } \\
\text { sion. }\end{array}$ & $\begin{array}{l}\text { RA6: Business develop- } \\
\text { ment treats strategies as } \\
\text { market-spanning, collabo- } \\
\text { rative plans aimed at re- } \\
\text { sourcefulness and emanci- } \\
\text { pation. }\end{array}$ \\
\hline
\end{tabular}

\section{Challenging Business Growth Assumptions in Light of a Post- Growth Context}

Accounting for context is a messy but important undertaking to increase the reliability and validity of theory (Rousseau \& Fried, 2001; Welter, 2011). For this paper, we adapt Johns' (2006, pp. 386, own emphasis) definition of context as "situational opportunities and constraints that affect behavior as well as functional relationships between variables". Given the focus on constraints in the post-growth discourse (Schmelzer, 2015), it is important to emphasise new paths and opportunities 
that can be provided by context (Johns, 2006; Welter, 2011). Furthermore, we investigate post-growth as a broader economic phenomenon (macro) and its impact on the growth of organisations (meso).

Post-growth can be described as a situation in which previous human expansion and impacts are reduced in the interest of long-term socio-ecological integrity (Jackson, 2009; Steffen et al., 2015). Such a conclusion is based on ecological and economic analyses. Compared to pre-industrial times, ecological conditions have deteriorated and even breached several proposed boundaries for the integrity of global ecosystems, and the outlook for the future is grim (Rockström et al., 2009; Steffen et al., 2015). These empirical findings support the computer model predictions made by Meadows et al. (1972) based on parameters such as population increases and resource use. Other criteria for limits to macro-level growth include ecological sink capacities (Jackson, 2009) and resource scarcity (Heinberg, 2007; Miegel, 2010). The proposed absolute decoupling of economic growth from its ecological impact opined by proponents of "green" or "sustainable growth" (OECD, 2014) is deemed impossible (Jackson, 2009; Paech, 2012). Thus, global-scale analyses suggest that continued expansion will exacerbate the already-chastening situation and ultimately confront unchallengeable walls.

In early-industrialised countries, real growth has lagged behind predictions and hopes for some time (e.g., Reuter, 1998). The reasons of this trend can be found in satisfied markets, asymptotical productivity gains, and diminished purchasing power (Keynes, 1943; Leontief, 1982). In his paper The Long Term Problem of Full Employment, Keynes describes the three-stage transition of post-war capitalist economies from demand-excessive to supply-excessive conditions. In the stagnating final stage, demand is widely satisfied making financial investments more lucrative and bubbles more likely. According to Keynes, economic collapse because of falling profit rates can be circumvented only by reducing working hours for the masses. Thus, economic activities in capitalist relations bear in them a restriction on endless growth (Zinn, 1994).

We therefore understand post-growth as an empirical change in institutions and logics based on resource scarcity and economic principles. This perspective triggers questions such as "what should firms strive for if growth is unfeasible," or "what does (firm) growth mean in a non-growing economy?" These questions stand in contrast to the normative concept and focus of degrowth. Building on these concepts, we identify three major challenges on the meso-level in line with the major questions of what, why, and how businesses grow: (1) the challenge of business growth as an increase in measurable outcomes, (2) the challenge of resource competition and dispositive path dependencies, and (3) the challenge of detrimental growth modes and strategies. 


\section{The Challenge of Business Growth as an Increase in Measurable Outcomes}

The post-growth context is characterised by absolute resource scarcity, thus turning economic activity in many areas into zero-sum games (Paech, 2012). Under such circumstances, it becomes problematic to conceptualise business growth merely in terms of an increase in size. In other words, firm size should not be the main explicandum in situations where increasing outputs are not the focus.

C1: Viewing business growth as an increase in outcomes is problematic in limited space.

\section{The Challenge of Resources and Dispositive Path Dependencies}

The Penrosean perspective suggests exploring and reconfiguring new resources to expand the firm, but it does not account for absolute limits of natural resources (Heinberg, 2007). Contrary to Penrose's beliefs, the absolute scarcity of paramount natural resources in the post-growth context (Heinberg, 2007) and the discovery of scarcity in previously non-scarce goods, e.g., minerals (Prior, Giurco, Mudd, Mason, \& Behrisch, 2012), might exacerbate corporate competition in corresponding markets. Simultaneously, extraction and utilisation of these resources also cause deteriorating local ecological and social conditions (Kimberling, 2005) and produce conflicts (Özkaynak et al., 2012).

C2: Competition for and exploration of resources under zero-sum conditions can result in detrimental effects.

Internally, bureaucratic complexity and expanding hierarchies may cause diseconomies of scale that consequently punish firm performance (Canbäck et al., 2006). Penrose (1959) did not consider diseconomies of scale as growth barriers so long as firms retain their entrepreneurial capabilities. She trusted organisations to adapt to increasing levels of complexity, which is evident in the existence of many large multinational conglomerates. However, the Penrosean logic is driven by the idea that firms can avoid financial diseconomies of scale. It does not consider potential negative environmental and social effects.

\section{C3: More hierarchies and structures can create diseconomies of scale.}

Further, the bureaucratic nature of large firms is usually associated with relative inflexibility (Crozier, 1964). Posse (2015) has identified multiple "growth drivers", i.e., conditions and constellations that incentivise or prescribe business growth. Among them are external financing, the existence of shareholders, structural benefits of size, a hierarchical structure within the firm combined with employees' desire to "climb the ladder", and the interplay between demand creation and symbolic consumption. 
The more entangled firms are in these growth-inducing constellations, the more difficult it is for managers to refrain from pursuing growth. Growth thus becomes an acquired taste (cf. Delmar \& Wiklund, 2008). These particular path dependencies become problematic in a post-growth context, because they promote continual growth despite absolute resource limitations. Instead, firms should remain flexible enough to change directions, i.e., to loosen their entanglement with (certain) growth drivers.

\section{C4: Path dependencies can promote ongoing expansion.}

\section{The Challenge of Detrimental Growth Modes and Strategies}

Having reached a certain size and organisational complexity, a firm's organic growth rate will stagnate, making M\&As the only way to foster growth (Lockett et al., 2011). Simultaneously, M\&As frequently fall short of expectations or even fail completely. This often results from severe adjustment costs that arise from complex integration processes (Steigenberger, 2017). Generally, adjustment costs seem to outbalance the benefits of an extended productive opportunity set.

\section{C5: Mo As are wasteful, problematic, and often only implemented as growth drivers.}

Finally, some business strategies are less suitable in the post-growth context than others. Cost-efficient strategies, for example, require economies of scale, i.e., growth that allows for reducing the variable cost of operations. Particularly in cost-competitive environments, lowering costs is paramount for survival. Firms retain their cost leadership only until the competition adapts to the cost leaders. Reichel (2013b) includes ecology as a sixth force in Porter's (1980) framework that fundamentally changes the power field.

C6: Adapting strategies and structures to industry standards is problematic because some strategies necessitate expansion.

\section{Revising Assumptions: From Growth towards Development}

\section{Growth as a Qualitative Process of Development}

Despite the prevalent conceptualisation of business growth as an increase in measurable outcomes, Penrose (1959, p. 1, emphasis in original) interprets the increase in size primarily as a by-product "of a process of development". The transition of a firm through the managerial re-arrangement of versatile resources goes to the core of Penrose's understanding of growth as development. Although this transitional process often appears to be continuous (Levie \& Lichtenstein, 2010) - particularly when considering life cycle models of the firm (Clarke, Holt, \& Blundel, 2014) Phelps et al. (2007) argue that firms might also experience more disruptive 'tipping points' (cf. Gladwell, 2000) that do not follow a particular sequence but are triggered by prior growth or environmental impacts. 
Firms encounter tipping points in relation to different organisational dimensions, such as people management, strategy, or formal systems (Phelps et al., 2007, p. 13). Encountering tipping points in the developmental process elicits change in the respective dimension(s) of the firm. The outlook of any particular organisation, however, is not merely determined by the firm's internal motivation. Rather, managers react to and interpret spaces of intelligibility that are framed by the firm's environment (Aldrich \& Martinez, 2001). From a co-evolutionary perspective, the firm's context may act both as a trigger of change as well as a source of inspiration for the firm's development with the environment (Clarke et al., 2014).

Taken together, we should rethink the label of business growth and instead refer to business development. Business development then encompasses a qualitative process of development that includes overcoming challenges. 'Qualitative' means that the focus does not lie on growth in terms of increasing sales figures, employment, assets, or outputs, as commonly assumed in the literature (Achtenhagen et al., 2010; Leitch et al., 2010); instead, the focus is on improvements in the nature of the firm.

\section{RA1: Business development describes an internal, qualitative process of improvement that includes overcoming challenges.}

\section{Growth as a Resourceful and Emancipative Process of Development}

Improvements can be judged by the firm's ability to develop in symbiosis with the post-growth context. Put differently, firms should utilise arising opportunities and overcome contextual challenges. In general, we argue that business development in a post-growth context must be resourceful and emancipative.

Planetary boundaries combined with absolute resource scarcity turn economic activity into a zero-sum game (Paech, 2012). In such contexts, competitive behaviour could exacerbate detrimental effects on ecology and society. The role of resources in business development must therefore differ from the common conceptions. Instead of viewing resources as a fundamental antecedent of growth, we need to subordinate business development to the preservation of natural resources. Stated differently, we need to treat resources as capital, not as income (Daly, 1974).

Operational arrangements that foster sufficiency by not increasing business scale but business quality might be worthy of consideration (Gebauer \& Mewes, 2015). Such operations and relationships with resources are suitable for conducting business in a post-growth context, because they move beyond the mere business case of eco- and socio-efficiency to include ecological equity, socio-effectiveness, sufficiency, and ecoeffectiveness (Dyllick \& Hockerts, 2002). For this purpose, Sachs (1993) introduced four criteria for sufficient business operations: lesser, slower, regionalisation, and de-commodification, which were recently reiterated by Palzkill and Schneidewind (2013). 
Taken together, the limitations on natural resources necessitate deriving value not from competitive resource-based growth processes (Nason \& Wiklund, 2018; Penrose, 1959; Pettus, 2001) but from developmental processes focusing on the resourceful treatment of scarce natural capital.

\section{RA2: Business development is resourceful, not resource-based.}

Sufficient business operations also necessitate certain business structures supporting positive macro-level effects in accordance with the post-growth context. Businesses must be able to emancipate themselves from current structural growth drivers (Posse, 2015). Accordingly, publicly traded companies that have an inbuilt incentive to increase ROI for shareholders (Posse, 2015) should make way for more collaborates and cooperatives, ideally in pursuit of pro-social or ecological purposes (Johanisova, Crabtree, \& Fraňková, 2013; Johanisova, Surinach Padilla, \& Parry, 2015).

For example, new ventures that are born in the post-growth context can reduce formal hierarchies (Parker et al., 2014), develop informal configurations (Diefenbach \& Sillince, 2011), and promote democratic structures (Hamel, 2011), including the corresponding legal arrangements. This increases stakeholder involvement in human resource management (HRM) (Guerci \& Rami Shani, 2014). The dynamics in post-growth contexts thus allow firms to actively challenge existing human resource ideologies (Nienhuser, 2011) in support of sustainable HRM (De Prins, Van Beirendonck, De Vos, \& Segers, 2014; Lis, 2012).

Already, many SMEs are more likely to refrain from external financing and form on a small scale that precludes hierarchical organisation and large-scale demand creation. Combined with a common lack of growth motivation resulting oftentimes from a concern for employee well-being and work-life balance among the firm's leaders (Cliff, 1998; Wiklund et al., 2003), SMEs are structurally well-defended against growth drivers (Posse, 2015). Although individual attitudes toward growth vary strongly between different types of owner-managers (Birley \& Westhead, 1994), empirical studies repeatedly find that 20 to $40 \%$ of all owner-managers have no intention to grow their firm (Cliff, 1998; Orser \& Hogarth Scott, 2002). Also, SMEs founded in the growth context adopt a long-term perspective that is often missing in large corporations, which are driven by annual reports and responsibilities to their (short-term-oriented) shareholders (Grothe \& Marke, 2012). The main problem thus arises for larger corporations experiencing negative effects of path dependencies in the form of growth pressures.

If large businesses want to counteract increasing diseconomies of scale, they also need to rethink hierarchies and strive for more self-managed arrangements, i.e. to include more democratisation in business structures and more rights, privileges, and power for the dependently employed (Bontrup \& Müller, 2006). Some prominent examples, such as W.L. Gore and Morning Star, already illustrate how large firms 
can benefit from more democratic corporate structures (Hamel, 2011). Empirical research further shows that interactions between individual business units are more prosperous when the units themselves initiate cooperation in a bottom-up manner (Martin \& Eisenhardt, 2010). Employee emancipation (Willmott \& Alvesson, 1992) could thus lead to further development because it is not achieved at the expense of product and service quality or human dignity (Laloux, 2014). Additionally, it can also increase work engagement and innovative behaviour (De Spiegelaere, Van Gyes, De Witte, \& Van Hootegem, 2015). Other options include reducing paid working hours for the dependently employed with simultaneous capacity building for self-sufficient, non-paid work and expertise (Keynes, 1943; Paech, 2012).

Some parameters indicate that post-growth contexts begin to exert pressure on large corporations. Those who see external limitations on their expansion and wish to survive actively freeze their expansion endeavours (Fisher et al., 2017). Instead of expanding and adding new customers, they aim to improve existing customer relationships and the quality of their value proposition. Although it does not follow that such strategic developments have no underlying growth intentions, they illustrate that the occurrence of diseconomies of scale already pushes large firms to rethink their existing business models. Such re-orientation in strategy might therefore support the shift of larger businesses toward developmental processes, in line with a post-growth context. The goal is not to overcome structural challenges for the sake of further business growth, as commonly assumed by growth theory (Greiner, 1972; Penrose, 1955), but to emancipate individuals and firms at large from structural growth drivers:

\section{RA3: Business development emancipates firms from structural growth drivers.}

Hart's (1995) natural resource-based view (NRBV) illustrates such gradual development toward more systemic changes in a firm's business model. The idea behind the NRBV is threefold. First, companies experience increasing pressure to reduce their pollution and improve their efficiency, e.g., via implementing total quality management. Second, such experiences will incentivise firms to "minimize the life-cycle environmental costs of their product systems" and obtain better product stewardship (Hart, 1995, p. 994). Third, these two 'stages of development' might incentivise more systemic changes to a firm's business model. In that sense, larger firms - similar to smaller market participants - will experience a push toward effectiveness and eventually sufficiency (Young \& Tilley, 2006).

However, how can businesses overcome the aforementioned structural barriers to shift from resource-based to a resourceful understanding of development? Although resources are limited in absolute terms, this transformation would require the input of resources to change the existing structures; i.e., it would initially cause increased resource consumption. 
Such dynamics assume that any type of resource is limited. However, the idea of planetary boundaries assumes limited resources, but only if they are defined as physical entities; if resources are defined in such a way that includes knowledge, creativity, or ideas, then not all resources are limited.

In that sense, we agree with Reichel (2017a, p. 109) that "[s]carcity is not a fundamental problem [...]. It is a problem of the social organization of economic transactions." Internal and external pressures then provide an opportunity for businesses to change their logics in accordance with resourcefulness and emancipation. Such changes are essentially fostered by entrepreneurial capabilities and resource versatility, thus appearing to make Penrose's (1959) ideas compatible with a post-growth context. The post-growth context then merely changes the objective of re-imagining and exploring hidden alternatives in existing resources:

RA4: Resource versatility provides the grounds for resourcefulness and emancipation, not the firm's ongoing expansion.

\section{Growth as a Collaborative Process of Development}

Post-growth contexts challenge acquisitive forms of growth modes if they are purely driven by growth necessities, such as internal or economic stagnation (Lockett et al., 2011). Nevertheless, some possible scenarios align acquisitive growth with a postgrowth context. For example, empirical evidence suggests that many SMEs resist adopting sustainable business practices because of time and monetary shortages when managing the complex expectations of multiple stakeholders (Grothe \& Marke, 2012). In addition, SMEs might also persist at mere subsistence levels, thus wasting scarce resources over long periods without creating value. Therefore, to provide stronger social or environmental contributions, a takeover by another firm could be more valuable for the post-growth context. In that sense, development also involves exit (Achtenhagen, Brunninge, \& Melin, 2017).

Similar to versatile resources, it is thus possible to accommodate M\&As in postgrowth contexts if they foster resourcefulness and emancipation, i.e., if the objectives of the acquisitions align with a post-growth context. Then the common objective of M\&As, namely, fostering organic growth (Lockett \& Wild, 2013; Penrose, 1959), shifts from benefits of individual market actors to benefits of the environment and society.

Additionally, strategic orientations can change from absorbing smaller firms toward other, expanded modes of cooperation via hybrid forms of growth (Achtenhagen et al., 2017; McKelvie \& Wiklund, 2010). These newly developed notions of growth modes include many collaborative alternatives that support a cooperative understanding of business development. Network-based growth strategies, for example, where firms develop by maintaining close relationships with their suppliers and customers, foster cooperation and provide an alternative to vertical integration (Acht- 
enhagen et al., 2017). Here, new ventures that are adept in these constellations might share knowledge with large corporations and support their transition by developing symbiotically.

Several empirical examples support the alignment of such growth modes with a post-growth context. Sachs' (1993) sufficient business criteria, for example, were empirically underscored by Palzkill, Wanner, and Markscheffel (2015) based on a network of social enterprises in Wuppertal, Germany. These organisations offer multiple sufficiency services, such as vernissages, repair cafés, or bike sharing, but most importantly, they engage in community building through co-working spaces and participatory structures. Instead of detached entities along a value chain, firms in a post-growth context could forge networks of close collaboration to upscale their (social) innovations (Gebauer \& Ziegler, 2013). Further empirical evidence is provided by Dini (1998; cited in Phelps et al., 2007), who investigated a 450-member SME hub in Chile, in which firms support each other's operations and form a border-transgressing collective.

Taken together, these examples advise current business growth theorising to assign a different role to growth modes in post-growth contexts. Breaking up the dichotomy of organic vs. acquisitive growth provides a plethora of different options including several cooperative modes. By means of collaboration instead of competition, it is then possible to align the emancipation of individual actors with shared environmental and societal goals.

\section{RA6: Business development builds on different forms of cooperation.}

The topic of competition further necessitates a discussion of market-oriented strategies and their role for business development in post-growth contexts. Among traditional strategies offered by Porter (1980), a niche focus is seen as less competitive and thus more appropriate for a post-growth context (Gebauer \& Mewes, 2015). In their sample of 11 SMEs in Germany that shifted from classical growth trajectories after systematically addressing the "growth question," Gebauer and Mewes (2015) found changes toward a strategic niche focus based on product segments, quality, and regions. Additionally, these firms tilted toward services instead of products, operated with capacity buffers, and rejected external financing in order to avoid growth pressures and to be resilient in times of crisis. They also explicitly decided against pursuing opportunities to quantitatively grow in order to first, maintain quality relationships along the supply chain with internal and external satisfaction at a high level, and second, to avoid falling into a spiral of reinforcing growth imperatives and pressures resulting from additional fixed and variable costs, interest rates on external loans, and hierarchical organisational re-arrangements. With such managerial behaviour, the appearance of "tipping points" led to more qualitative approaches to growth, not quantitative ones. 
New ventures can occupy context-specific emerging niches, differentiate between economic and dis-economic resource configurations, operate eco-effectively, and form networks with like-minded firms by reinterpreting value production along the supply chain collaboratively (Gebauer \& Ziegler, 2013). When approaching tipping points, such firms are likely to refrain from growth in size because of the normative framework in which their managers operate or their niche existence based on product quality or region, as evidenced by Gebauer and Mewes (2015).

Reichel (2013) further argues that a post-growth context might expand Porter's Five Forces by introducing ecological and societal limits as additional "forces". This approach would extend the strategic horizon beyond cost leadership, diversification, or a niche focus to include additional strategies. Reichel (2017b) proposes (1) domination, i.e., an aggressive zero-sum game in defence of scarce resources, (2) reduction, i.e., a focus on the sufficiency of consumption, (3) renovation, i.e., the promotion of product service systems and repair, and (4) collaboration, i.e., a focus on value co-creation. Reichel (2013) also argues that strategic planning will become even more paramount in the new context, particularly if more diverse indicators are considered in the form of triple-bottom-line accounting.

The argument ascribes further importance to the strategic balance between shortterm and long-term considerations. On the topic of climate change, firms that strongly polarise between the short and long term tend to be reactive and narrowminded and to despise the problem (Slawinski \& Bansal, 2015). Conversely, firms that juxtapose between the short and long term invent and apply more inclusive solutions (Slawinski \& Bansal, 2015). However, particularly large firms will not be able to switch their strategic positioning quickly and dramatically. Rather, their point is to acknowledge ambidexterity and to actively address intertemporal tensions instead of ignoring them (Hahn, Pinkse, Preuss, \& Figge, 2016).

Taken together, the above illustrates an overlap of growth modes and market-oriented strategies in post-growth contexts. When businesses develop in collaborative modes and rely upon network structures, the meaning of strategy needs to shift dramatically. "Replacing 'organization' with 'networks', with diverse and heterarchical networks of value creation, makes the inner core of the form of the firm look very different" (Reichel, 2017, p. 103). In this way, strategies and strategic management are no longer tools or requisites for individual market actors to compete, as commonly understood by growth theories (Barney, 1991; Demir, Wennberg, \& McKelvie, 2017; Porter, 1980); rather, strategies include multiple actors within a network who plan ahead and democratically determine how to achieve shared environmental and societal goals.

RA6: Business development treats strategies as market-spanning, collaborative plans aimed at resourcefulness and emancipation. 


\section{Towards a Theory of Business Development in Post-Growth Contexts}

What is the role of business growth in the context of post-growth economies where individual firms are confronted with absolute resource scarcity and stagnating growth rates? While most of the literature on business growth remains quiet and possibly ignorant of these contextual effects, a niche stream of literature on postgrowth organisations has recently provided some valuable starting points for theoretical investigations. However, existing contributions either focus on particular aspects of post-growth organisations without accounting for the bigger picture of the firm, or they derive their arguments from radically different positions that impede a common research agenda. Borrowing the method of problematisation (Alvesson \& Sandberg, 2011), we challenged prominent views in entrepreneurship and management literature on business growth and illustrated another perspective that aligns with the idea of post-growth economies: business development as a qualitative and collaborative process that subordinates the role of business growth to foster resourcefulness and the emancipation of market participants.

The idea builds on six revised assumptions that provide a foundation for future theorisation of business development in post-growth contexts. First, business development describes an internal, qualitative process of improvement that includes overcoming challenges. Rather than focusing on growth as an increase in firm size, this view rejuvenates developmental and processual definitions of business growth by focusing on qualitative dimensions (cf. Penrose, 1959). Consequently, we suggest avoiding the term 'business growth' altogether when discussing post-growth organisations and instead label it 'business development.'

The processual and developmental perspective in itself does not suffice to account for post-growth contexts. In addition, the remaining five revised assumptions must outline the focus and boundaries of business development.

The second assumption reverses the role of resources. Instead of viewing resources as mere inputs for outcome-increasing business growth, they become a focal aspect of investigation. In line with the absolute scarcity of natural resources, the following question arises: How can business development foster the resourcefulness of individual market actors?

Third, we acknowledge the problem of path dependencies fostering continued expansion of individual firms. Furthermore, increasing hierarchies and structures create detrimental diseconomies of scale. If businesses are to align with post-growth contexts, they need to break with growth drivers that dictate ongoing expansion. Further research should thus address how business development can emancipate individual market actors from structural growth drivers.

Fourth, if businesses need to shift from their current positions to accommodate emancipation and resourcefulness, then they require flexibility and entrepreneurial 
capabilities. Accordingly, the Penrosean idea of versatile resources (cf. Nason \& Wiklund, 2018) still applies, although with a different focal outcome. Instead of theorising the role of versatile resources for their potential to increase the firm's size, we need to investigate how businesses make use of versatile resources to increase resourcefulness and emancipation.

Fifth, the focus on broader economic, environmental, and societal goals that results from a post-growth context potentially clashes with the aims and goals of individual market participants. To overcome such challenges, it is necessary to gradually question the notion of businesses as singular entities that follow egoistic, profitmaximising goals (cf. Penrose, 1959). Instead, our fifth revised assumption argues that business development accounts for 'growth modes' that build on collaborative forms of organisation. In line with common goals, collaborative forms of business development dilute the notion of singular entities. Although initial theorisations on these topics exist (e.g. Reichel, 2017a), future research should investigate how such collaborative forms gradually transform individual market actors.

Finally, increased collaboration will also require a fundamental revision of predominant notions of strategy and strategic management. Instead of limiting them to behavioural guidelines for individual firms, they can be reimagined as market-spanning, collaborative plans aimed at resourcefulness and emancipation. Broadening strategy to include multiple market actors provides vast research opportunities.

Taken together, these six revised assumptions illustrate a common research agenda that promotes a theory of business development in post-growth contexts. Starting with common assumptions in the business growth literature and acknowledging some of their applicability, the proposed approach has the potential to gain broader attention (cf. Roth, 2016). Although the approach suggests focusing on qualitative developmental processes, it does not exclude quantification of our suggested dimensions for larger-scale studies. Quite the opposite, quantification of the proposed assumptions might further legitimise research on post-growth organisations.

The proposed revisions to current growth theorising also provide an opportunity to close the gap between theory and practice (Achtenhagen et al., 2010). Challenges posed by post-growth contexts lead growth theory to focus on qualitative aspects of development that reflect the understanding of business growth among practitioners. Further, the suggested changes in understanding could also contribute to the 'deeconomisation' of society (Roth, 2017, p. 9). Ideally, future research on post-growth organisations would support a qualitative shift in business education toward "soft skills, [...] critical thinking, and a broad, holistic triple-bottom-line understanding of management with the development of a shared vision for all stakeholders" (Nonet, Kassel, \& Meijs, 2016, p. 729). Young students and future managers would obtain the necessary skills and capabilities to develop firms in new directions in a post-growth context. To achieve this goal, however, future research on post-growth 
organisations must act in concert. The suggested multidimensional perspective provides some guidelines for such a common research agenda.

\section{Acknowledgements}

We acknowledge the special issue editors and the two anonymous reviewers for their outstanding feedback that helped to materially improve our work. We presented early ideas for this paper during a research seminar at Jönköping International Business School, and we thank all participants for their valuable comments. Finally, we are grateful to Leona Achtenhagen, Sverre Spoelstra, Massimo Baù, and Sarah Fitz-Koch for their support and useful comments on earlier versions of this paper.

\section{References}

Achtenhagen, L., Brunninge, O., \& Melin, L. (2017). Patterns of dynamic growth in mediumsized companies: Beyond the dichotomy of organic versus acquired growth. Long Range Planning, 50(4), 457-471.

Achtenhagen, L., Naldi, L., \& Melin, L. (2010). "Business growth" - Do practitioners and scholars really talk about the same thing? Entrepreneurship Theory and Practice, 34(2), 289-316.

Agarwal, R., Sarkar, M. B., \& Echambadi, R. (2002). The conditioning effect of time on firm survival: An industry life cycle approach. Academy of Management Journal, 45(5), 971-994.

Aldrich, H. E. (1999). Organizations Evolving. Newbury Park, CA: Sage Publications.

Aldrich, H. E., \& Martinez, M. A. (2001). Many are called, but few are chosen: An evolutionary perspective for the study of entrepreneurship. Entrepreneurship Theory and Practice, 25(1), 4156.

Alvesson, M., \& Sandberg, J. (2011). Generating research questions through problematization. Academy of Management Review, 36(2), 247-271.

Atzeni, M. (2012). An introduction to theoretical issues. In M. Atzeni (Ed.), Alternative Work Organizations (pp. 1-24). New York: Palgrave Macmillan.

Barney, J. (1991). Firm resources and sustained competitive advantage. Journal of Management, 17(1), 99-120.

Baum, J. R., \& Locke, E. A. (2004). The relationship of entrepreneurial traits, skill, and motivation to subsequent venture growth. Journal of Applied Psychology, 89(4), 587-598.

Baum, J. R., Locke, E. A., \& Smith, K. G. (2001). A multidimensional model of venture growth. Academy of Management Journal, 44(2), 292-303.

Birley, S., \& Westhead, P. (1994). A taxonomy of business start-up reasons and their impact on firm growth and size. Journal of Business Venturing, 9(1), 7-31.

Bontrup, H.-J., \& Müller, J. (2006). Wirtschaftsdemokratie: Alternativen zum Shareholder-Kapitalismus. Hamburg: VSA-Verlag.

Box, T. M., Watts, L. R., \& Hisrich, R. D. (1994). Manufacturing entrepreneurs: An empirical study of the correlates of employment growth in the Tulsa MSA and rural East Texas. Journal of Business Venturing, 9(3), 261-270.

Canbäck, S., Samouel, P., \& Price, D. (2006). Do diseconomies of scale impact firm size and performance? A theoretical and empirical overview. Journal of Managerial Economics, 4(1), 27-70. 
Clarke, J., Holt, R., \& Blundel, R. (2014). Re-imagining the growth process: (Co)-evolving metaphorical representations of entrepreneurial growth. Entrepreneurship \& Regional Development, 26(3-4), 234-256.

Cliff, J. E. (1998). Does one size fit all? Exploring the relationship between attitudes towards growth, gender, and business size. Journal of Business Venturing, 13(6), 523-542.

Covin, J. G., \& Slevin, D. P. (1988). The influence of organization structure on the utility of an entrepreneurial top management style. Journal of Management Studies, 25(3), 217-234.

Covin, J. G., \& Slevin, D. P. (1990). New venture strategic posture, structure, and performance: An industry life cycle analysis. Journal of Business Venturing, 5(2), 123-135.

Cowling, M. (2006). Early stage survival and growth. In S. Parker (Ed.), The Life Cycle of Entrepreneurial Ventures (Vol. 3, pp. 479-506). Boston, MA: Springer US.

Crozier, M. (1964). The Bureaucratic Phenomenon. Chicago: The University of Chicago Press.

Cyert, R. M., \& March, J. G. (1963). A behavioral theory of the firm. Englewood Cliffs, NJ: Prentice-Hall.

Daly, H. E. (1974). The economics of the steady state. American Economic Review, 64(2), 15-21.

Davidsson, P. (1989). Entrepreneurship - And after? A study of growth willingness in small firms. Journal of Business Venturing, 4(3), 211-226.

Davidsson, P. (1991). Continued entrepreneurship: Ability, need, and opportunity as determinants of small firm growth. Journal of Business Venturing, 6(6), 405-429.

Davidsson, P., Achtenhagen, L., \& Naldi, L. (2010). Small Firm Growth. Foundations and Trends in Entrepreneurship, 6(2), 69-166.

De Prins, P., Van Beirendonck, L., De Vos, A., \& Segers, J. (2014). Sustainable HRM: Bridging theory and practice through the "respect openness continuity (ROC)-" model. Management Revue, 25(4), 263-284.

De Spiegelaere, S., Van Gyes, G., De Witte, H., \& Van Hootegem, G. (2015). Job design, work engagement and innovative work behavior: A multi-level study on Karasek's learning hypothesis. Management Revue, 26(2), 123-137.

Delmar, F., \& Wiklund, J. (2008). The effect of small business managers' growth motivation on firm growth: A longitudinal study. Entrepreneurship Theory and Practice, 32(3), 437-457.

Demir, R., Wennberg, K., \& McKelvie, A. (2017). The strategic management of high-growth firms: A review and theoretical conceptualization. Long Range Planning, 50(4), 431-456.

Dettmers, J., Kaiser, S., \& Fietze, S. (2013). Theory and practice of flexible work: Organizational and individual perspectives. Management Revue, 24(3), 155-161.

Diefenbach, T., \& Sillince, J. A. A. (2011). Formal and informal hierarchy in different types of organization. Organization Studies, 32(11), 1515-1537.

Dietsche, C., \& Liesen, A. (2013). Wachstumsneutrale Unternehmen. Ökologisches Wirtschaften, 28(1), 14.

Dini, M. (1998). Chilean experience promoting the implementation of SMEs networks. Presented at the UNIDO Joint Learning Workshop, Bologna.

Douglas, E. J. (2013). Reconstructing entrepreneurial intentions to identify predisposition for growth. Journal of Business Venturing, 28(5), 633-651.

Dyllick, T., \& Hockerts, K. (2002). Beyond the business case for corporate sustainability. Business Strategy and the Environment, 11(2), 130-141. 
Fisher, M., Gaul, V., \& Kleinberger, H. (2017). Curing the addiction to growth. Harvard Business Review, 95(1), 66-74.

Garnsey, E., Stam, E., \& Heffernan, P. (2006). New firm growth: Exploring processes and paths. Industry and Innovation, 13(1), 1-20.

Gavetti, G., Greve, H. R., Levinthal, D. A., \& Ocasio, W. (2012). The behavioral theory of the firm: Assessment and prospects. Academy of Management Annals, 6(1), 1-40.

Gebauer, J., \& Mewes, H. (2015). Qualität und Suffizienz in stabilitätsorientierten KMU. UmweltWirtschaftsForum, 23(1-2), 33-40.

Gebauer, J., \& Ziegler, R. (2013). Gemeinsam sind wir groß. Ökologisches Wirtschaften, 28(1), $21-22$.

Gladwell, M. (2000). The Tipping Point: How Little Things Can Make a Big Difference. Boston: Little Brown.

Greiner, L. E. (1972). Evolution and revolution as organizations grow. Harvard Business Review, 50(4), 37-46.

Grothe, A., \& Marke, N. (2012). Nachhaltiges Wirtschaften - eine besondere Herausforderung für KMU. In A. Grothe (Ed.), Nachhaltiges Wirtschaften für KMU. München: oekonom verlag.

Guerci, M., \& Rami Shani, A. B. (2014). Stakeholder involvement in Human Resource Management practices: Evidence from Italy. Management Revue, 25(2), 80-102.

Gundry, L. K., \& Welsch, H. P. (2001). The ambitious entrepreneur: High growth strategies of women-owned enterprises. Journal of Business Venturing, 16(5), 453-470.

Hahn, T., Pinkse, J., Preuss, L., \& Figge, F. (2016). Ambidexterity for corporate social performance. Organization Studies, 37(2), 213-235.

Hamel, G. (2011). First, let's fire all the managers. Harvard Business Review, 89(12), 48-60.

Hart, S. L. (1995). A natural-resource-based view of the firm. Academy of Management Review, 20(4), 986.

Heinberg, R. (2007). Peak Everything: Waking Up to the Century of Declines. Gabriola Islands, Canada: New Society Publishers.

Hofer, C. W., \& Charan, R. (1984). The transition to professional management: Mission impossible? American Journal of Small Business, 9(1), 1-11.

Ireland, R. D., \& Hitt, M. A. (1997). Performance strategies for high-growth entrepreneurial firms. In P. D. Reynolds, W. D. Bygrave, N. M. Carter, P. Davidsson, W. B. Gartner, C. M. Mayson, \& P. P. McDougall (Eds.) (pp. 90-104). Presented at the Frontiers in Entrepreneurship Research, Wellesley, MA.

Ireland, R. D., Hitt, M. A., Camp, S. M., \& Sexton, D. L. (2001). Integrating entrepreneurship and strategic management actions to create firm wealth. Academy of Management Executive, 15(1), 49-63.

Jackson, T. (2009). Prosperity without Growth: Economics for a Finite Planet. London: Earthscan.

Johanisova, N., Crabtree, T., \& Fraňková, E. (2013). Social enterprises and non-market capitals: A path to degrowth? Journal of Cleaner Production, 38, 7-16.

Johanisova, N., Surinach Padilla, R., \& Parry, P. (2015). Co-operatives. In G. D'Alisa, F. Demaria, \& G. Kallis (Eds.), Degrowth: A vocabulary of a new era (pp. 152-155). Oxon, UK \& New York, USA: Routledge.

Johns, G. (2006). The essential impact of context on organizational behavior. Academy of Management Review, 31(2), 386-408. 
Johnsen, C. G., Nelund, M., Olaison, L., \& Sørensen, B. M. (2017). Organizing for the postgrowth economy. Ephemera, 17(1), 1-21.

Keynes, J. M. (1943). The long-term problem of full employment. The Collected Writings of John Maynard Keynes, 27, 320-325.

Kimberling, J. (2005). Indigenous peoples and the oil frontier in Amazonia: The case of Ecuador, ChevronTexaco, and Aguinda v. Texaco. New York University Journal of International Law and Politics, 38(3), 413-664.

Kolvereid, L. (1992). Growth aspirations among Norwegian entrepreneurs. Journal of Business Venturing, 7(3), 209-222.

Laloux, F. (2014). Reinventing organizations. Brussels: Nelson Parker.

Leitch, C., Hill, F., \& Neergaard, H. (2010). Entrepreneurial and business growth and the quest for a "comprehensive theory": Tilting at windmills? Entrepreneurship Theory and Practice, 34(2), 249-260.

Leontief, W. W. (1982). The distribution of work and income. Scientific American, 247(3), 188204.

Levie, J., \& Lichtenstein, B. B. (2010). A terminal assessment of stages theory: Introducing a dynamic states approach to entrepreneurship. Entrepreneurship Theory and Practice, 34(2), 317350.

Lis, B. (2012). The relevance of corporate social responsibility for a sustainable human resource management: An analysis of organizational attractiveness as a determinant in employees' selection of a (potential) employer. Management Revue, 23(3), 279-295.

Lockett, A., \& Wild, A. (2013). A Penrosean theory of acquisitive growth. Business History, 55(5), 790-817.

Lockett, A., Wiklund, J., Davidsson, P., \& Girma, S. (2011). Organic and acquisitive growth: Reexamining, testing and extending Penrose's growth theory. Journal of Management Studies, 48(1), 48-74.

Low, M. B., \& MacMillan, I. C. (1988). Entrepreneurship: Past research and future challenges. Journal of Management, 14(2), 139-161.

Lumpkin, G. T., \& Dess, G. G. (2001). Linking two dimensions of entrepreneurial orientation to firm performance: The moderating role of environment and industry life cycle. Journal of Business Venturing, 16(5), 429-451.

Martin, J. A., \& Eisenhardt, K. M. (2010). Rewiring: Cross-business-unit collaborations in multibusiness organizations. Academy of Management Journal, 53(2), 265-301.

McKelvie, A., \& Wiklund, J. (2010). Advancing firm growth research: A focus on growth mode instead of growth rate. Entrepreneurship Theory and Practice, 34(2), 261-288.

Meadows, D. H., Meadows, D. L., \& Randers, J. (1972). The Limits to Growth. New York: Universe Books.

Miegel, M. (2010). Exit. Berlin: Ullstein Propyläen.

Miner, J. B., Smith, N. R., \& Bracker, J. S. (1989). Role of entrepreneurial task motivation in the growth of technologically innovative firms. Journal of Applied Psychology, 74(4), 554-560.

Nason, R. S., \& Wiklund, J. (2018). An assessment of resource-based theorizing on firm growth and suggestions for the future. Journal of Management, 44(1), 32-60.

Nienhuser, W. (2011). Empirical research on human resource management as a production of ideology. Management Revue, 22(4), 367-393. 
Nonet, G., Kassel, K., \& Meijs, L. (2016). Understanding responsible management: Emerging themes and variations from European business school programs. Journal of Business Ethics, 139(4), 717-736.

OECD. (2014). Report on the OECD framework for inclusive growth. Paris: Organisation for Economic Cooperation and Development (OECD).

Orser, B., \& Hogarth Scott, S. (2002). Opting for growth: Gender dimensions of choosing enterprise development. Canadian Journal of Administrative Sciences, 19(3), 284-300.

Özkaynak, B., Rodriguez-Labajos, B., Arsel, M., Avc1, D., Carbonell, M. H., Chareyron, B., et al. (2012). Mining Conflicts around the World: Common Grounds from Environmental Justice Perspective. EJOLT Report No. 7 (pp. 1-202).

Paech, N. (2012). Liberation from Excess: The Road to a Post-Growth Economy. (B. Liebelt, Trans.). München: oekonom verlag.

Palzkill, A., \& Schneidewind, U. (2013). Suffizienz als Business Case. Ökologisches Wirtschaften, 28(1), 1-3.

Palzkill, A., Wanner, M., \& Markscheffel, F. (2015). Suffizienz als Geschäftsmodell. UmweltWirtschaftsForum, 23(1-2), 69-76.

Parker, M., Cheney, G., Fournier, V., \& Land, C. (2014). The question of organization: A manifesto for alternatives. Ephemera, 14(4), 623-638.

Penrose, E. T. (1955). Limits to the growth and size of firms. American Economic Review, 45(2), 531-543.

Penrose, E. T. (1959). The Theory of the Growth of the Firm. New York: John Wiley \& Sons.

Pettus, M. L. (2001). The resource-based view as a developmental growth process: Evidence from the deregulated trucking industry. Academy of Management Journal, 44(4), 878-896.

Phelps, R., Adams, R., \& Bessant, J. (2007). Life cycles of growing organizations: A review with implications for knowledge and learning. International Journal of Management Reviews, 9(1), 130.

Porter, M. E. (1980). Competitive Strategy. New York: The Free Press.

Posse, D. (2015). Zukunftsfähige Unternehmen in einer Postwachstumsgesellschaft. Eine theoretische und empirische Untersuchung. Marburg: metropolis.

Prior, T., Giurco, D., Mudd, G., Mason, L., \& Behrisch, J. (2012). Resource depletion, peak minerals and the implications for sustainable resource management. Global Environmental Change, 22(3), 577-587.

Ram, M. (2000). "Professionals at work" - Transition in a small service firm. Journal of Small Business and Enterprise Development, 7(1), 69-77.

Reichel, A. (2013). Strategische Handlungsoptionen für Unternehmen in der Postwachstumsökonomie. In Jahrbuch Nachhaltige Ökonomie (pp. 191-219).

Reichel, A. (2017a). Shape of things to come: From the "laws of form" to management in the post-growth economy. Ephemera, 17(1), 89-118.

Reichel, A. (2017b). Wachstumsindifferenz: Generische Unternehmensstrategien für die Postwachstumsökonomie. In T. Wunder (Ed.), CSR und Strategisches Management (3rd ed., Vol. 102, pp. 325-339). Berlin, Heidelberg: Springer Gabler, Berlin, Heidelberg.

Reuter, N. (1998). Wachstumseuphorie und Verteilungsrealität. Marburg: Metropolis.

Rockström, J., Steffen, W., Noone, K., Persson, Å., Chapin, F. S. I., Lambin, E. F., et al. (2009). A safe operating space for humanity. Nature, 461(7263), 472-475. 
Roth, S. (2016). Growth and function: A viral research program for next organisations. International Journal of Technology Management, 72(4), 296.

Roth, S. (2017). Marginal economy. Growth strategies for post-growth societies. Journal of Economic Issues, 51(4), 1033-1046.

Rousseau, D. M., \& Fried, Y. (2001). Location, location, location: Contextualizing organizational research. Journal of Organizational Behavior, 22(1), 1-13.

Sachs, W. (1993). Die vier E’s. Merkposten für einen maß-vollen Wirtschaftsstil. Politische Ökologie, 11(33), 69-72.

Schmelzer, M. (2015). Spielarten der Wachstumskritik. In Le Monde Diplomatique and Kolleg Postwachstumsgesellschaften (Eds.), Atlas der Globalisierung: Weniger wird mehr. Berlin: taz Verlag.

Schmelzer, M. (2016). The Hegemony of Growth. Cambridge: Cambridge University Press.

Slawinski, N., \& Bansal, P. (2015). Short on time: Intertemporal tensions in business sustainability. Organization Science, 26(2), 531-549.

Steffen, W., Richardson, K., Rockström, J., Cornell, S. E., Fetzer, I., Bennett, E. M., et al. (2015). Planetary boundaries: Guiding human development on a changing planet. Science, 347(6223), 1259855.

Steigenberger, N. (2017). The challenge of integration: A review of the M\&A integration literature. International Journal of Management Reviews, 19(4), 408-431.

Titus, V. K., Jr., Covin, J. G., \& Slevin, D. P. (2011). Aligning strategic processes in pursuit of firm growth. Journal of Business Research, 64(5), 446-453.

Upton, N., Teal, E. J., \& Felan, J. T. (2001). Strategic and business planning practices of fast growth family firms. Journal of Small Business Management, 39(1), 60-72.

Welter, F. (2011). Contextualizing entrepreneurship - Conceptual challenges and ways forward. Entrepreneurship Theory and Practice, 35(1), 165-184.

Wernerfelt, B. (1984). A resource-based view of the firm. Strategic Management Journal, 5(2), $171-180$.

Wiklund, J. (1998). Small firm growth and performance: Entrepreneurship and beyond. Dissertation Series, Jönköping International Business School, Jönköping.

Wiklund, J., \& Shepherd, D. A. (2003). Aspiring for, and achieving growth: The moderating role of resources and opportunities. Journal of Management Studies, 40(8), 1919-1941.

Wiklund, J., Davidsson, P., \& Delmar, F. (2003). What do they think and feel about growth? An expectancy-value approach to small business managers' attitudes toward growth. Entrepreneurship Theory and Practice, 27(3), 247-270.

Wiklund, J., Patzelt, H., \& Shepherd, D. A. (2009). Building an integrative model of small business growth. Small Business Economics, 32(4), 351-374.

Willmott, H., \& Alvesson, M. (1992). On the idea of emancipation in management and organization studies. Academy of Management Review, 17(3), 432-464.

Young, W., \& Tilley, F. (2006). Can businesses move beyond efficiency? The shift toward effectiveness and equity in the corporate sustainability debate. Business Strategy and the Environment, 15(6), 402-415.

Zinn, K. G. (1994). Die Wirtschaftskrise. Wachstum oder Stagnation. Zum ökonomischen Grundproblem reifer Volkswirtschaften. Mannheim: B.I. Taschenbuchverlag. 